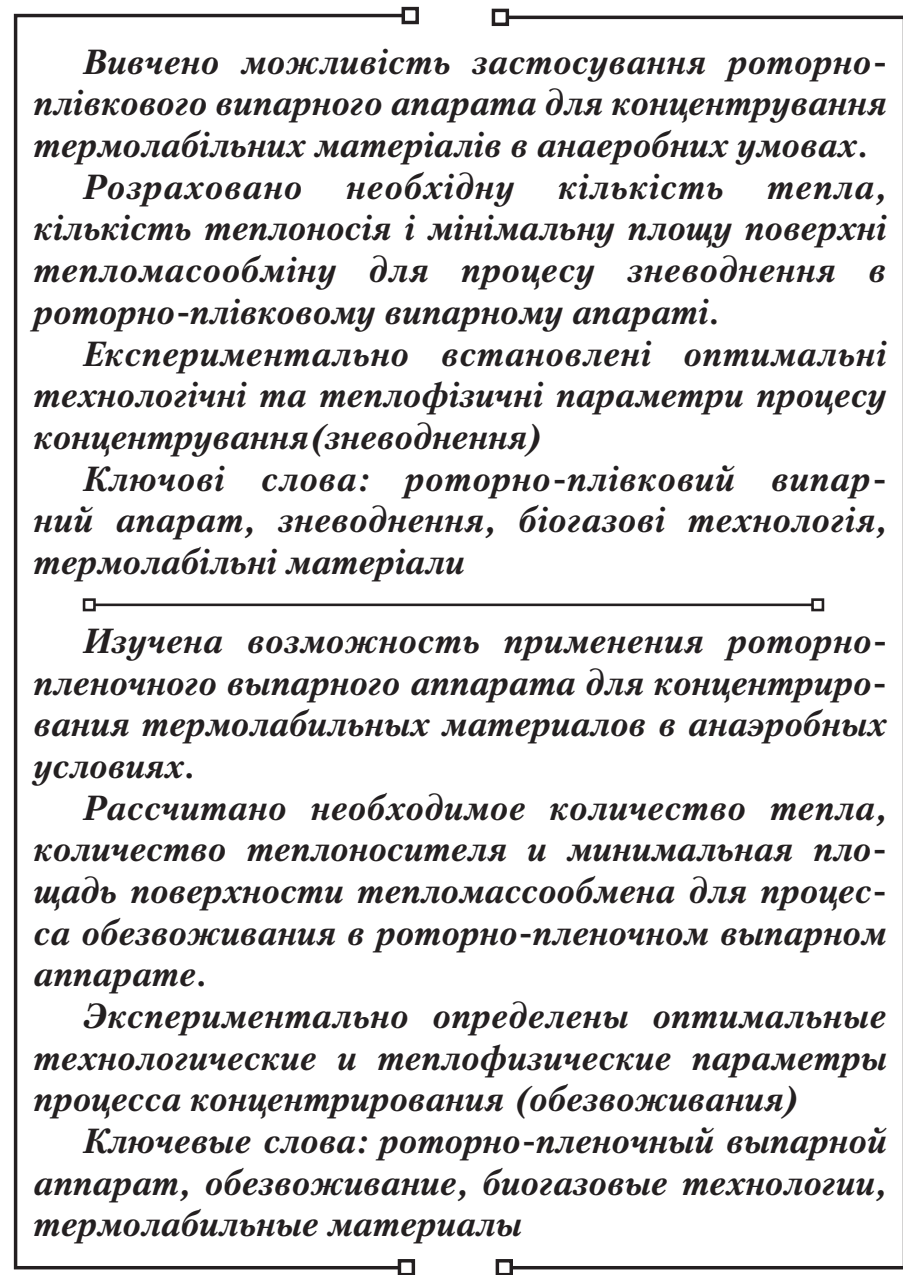

УДК 663.1, 66.974.434

ДОСЛІДЖЕННЯ ПРОЦЕСУ ЗНЕВОДНЕННЯ МІКРОБІОЛОГІЧНИХ MATEPIAЛІВ B POTOPHOПЛІВКОВОМУ ВИПАРНОМУ АПАРАТІ

О. М. Ободович

Доктор технічних наук

Член-корр. Академії технологічних наук Головний науковий співробітник*

E-mail: icsushka@gmail.com

C. I. Костик

Молодший науковий співробітник, аспірант *

E-mail: kostyksergey@ukr.net

*Відділ ТДС

Інститут технічної теплофрізики НАН України вул. Булаховського 2, м.Київ, Україна, 03164

\section{1. Вступ}

На сьогоднішній день концентрування (зневоднення) термолабільних мікробіологічних матеріалів $є$ актуальною проблемою в мікробіологічній, харчовій, фармацевтичній промисловості та в ресурсоенергозберігаючих технологіях, таких як біогазова технологія переробки органічних відходів. Не менш актуальною задачею є необхідність створення методів та підходів для концентрування анаеробних мікробіологічних препаратів, тобто тих препаратів, які втрачають свою життєздатність при наявності кисню. Концентрування таких мікробіологічних препаратів являється складною задачею, оскільки в якості теплоносія неможливо використовувати повітря, а також необхідно вести процес в термолабільних умовах, тобто тоді, коли температура розчину, що концентрується, не перевищує температуру мокрого термометра [1,2].

\section{2. Аналіз літературних даних та публікацій}

Більшість мікробіологічних препаратів, які підлягають процесу зневоднення, є суспензіі, дисперсійне середовище яких є в свою чергу розчинами органічних та неорганічних з'єднань. В самій мікробній клітині також знаходиться майже $80-85$ \% води. Частина води знаходиться у вільному стані, частина зв'язана.
Зменшення кількості води в клітині тягне за собою глибокі зміни в усій колоїдній системі. Білкові речовини - основні елементи мікробної клітини, тому значна втрата води приводить до денатурації білка, що є незворотнім процесом втрати життедіяльності [3, 4].

Ряд вчених: Б. И. Бланков, Д. П. Клебанов, С. Г. Колесов, К. Сміт вважають, що сушка та заморожування, по суті, близькі процеси, так як і в тому, і в іншому випадку клітина втрачає воду. При сушці вода видаляється з клітини, а при заморожуванні переходить в твердий недієздатний стан.

В залежності від способу переводу живої клітини в стан анабіозу відрізняють анабіоз при заморожуванні, або холодний анабіоз, та анабіоз при сушці, або сухий анабіоз. В наших дослідах розглядається стан клітини біомаси, яка зневоднюється без застосування холоду.

Порівнюючи різні методи зневоднення живої клітинної біомаси мікроорганізмів та аналізуючи причини інактивації клітин мікроорганізмів при зневодненні та механізм переміщення вологи в клітинах, зробимо оцінку застосування способу зневоднення (сушки):

- ліофільна сушка - з меншим ступенем інактивує ферменти, добре зберігає життєздатність клітин, але при ліофільній сушці на структури клітини діють деякі від'ємні фактори, які не мають місця при конвективній сушці [5, 6]; 
- розпилювальна сушка - процес зневоднення йде швидко, тому на життєдіяльність істотно не впливають ні ферментативні процеси, ні підвищення концентрації електролітів, але можливі випадки пересушки поверхні частинок та перегрів висушеного матеріалу [7, 8];

- конвективні методи сушки найбільше застосовують для зневоднення багатотоннажної мікробної біомаси в промисловості - при виробництві сухих хлібопекарських дріжджів, препаратів молочнокислих бактерій, різних заквасок, біопрепаратів [9].

\section{3. Постановка задачі дослідження}

Об’єкт дослідження - препарати мікробіологічного синтезу, які пропонуються до промислового виробництва.

Мета дослідження - на відібраних штаммах анаєробів, які пройшли стадію вирощування і проявили високу біологічну активність, відпрацювання технологічного процесу; визначення оптимальних технологічних та теплофізичних параметрів, режимів роботи роторно-півкового випарного апарату.

Метод дослідження - напрацювання зразків біомаси з подальшим її зневодненням методом концентрування.

\section{4. Енергоефективна установка для зневоднення мікробіологічних матеріалів}

В ІТТФ НАН України запропонований енергоефективна установка для концентрування анаеробних мікроорганізмів метаногенів (рис. 1), основним апаратом якого є роторно-плівковий випарний апарат (РПВА), який дозволяє концентрувати мікробіологічні матеріали в анаеробних, термолабільних умовах. Пристрій працює наступним чином: в об'єм РПВА 3, через технологічний штуцер 11 завантажується культуральна рідина, яка підлягає концентруванню до певного рівня, встановленого регламентом. В калорифері 1 відбувається підігрів робочого теплоносія (вуглекислий газ $\mathrm{CO}_{2}$ ). Вентилятор 5 приводить в рух робочий теплоносій, при цьому відбувається його циркуляція по контуру в об'ємі пристрою.

РПВА 3 на валу 15 має ряд дисків 16, які частково занурені в культуральний розчин, що концентрується (рис. 2). Привод 17 РПВА приводить в обертовий рух диски 16, які розміщені на валу 15 . Диски 16 при обертанні на своїй поверхні виносять культуральну рідину в зону контакту з теплоносієм, який продувається через об'єм РПВА 3. Частина вологи випаровується 3 поверхні дисків 16 і разом 3 теплоносієм рухається по трубопроводу 6. При закритому вентилі 7 , теплоносій разом із парами вологи проходить через патрон із силікагелем 8. В патроні із силікагелем 8 відбувається поглинання парів вологи, і на виході з патрону у трубопровід 6 повертається тільки робочий теплоносій, який знову потрапляє в калорифер 1, в якому відбувається його підігрів до заданої регламентом температури. Готовий концентрат вивантажується з РПВА 3 в контейнер. Процес повторюється циклічно.

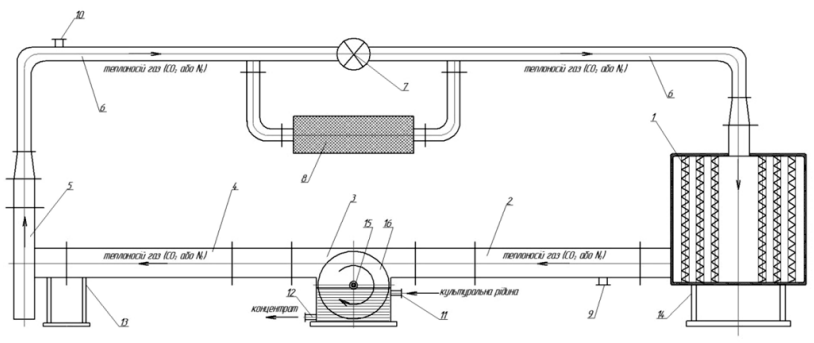

Рис. 1. Схема експериментального стенда установки для концентрування термолабільних розчинів: 1 - калорифер; 2, 4, 6 - трубопровід; 3 - РПВА, 5 - вентилятор; 7 - вентиль запірний; 8 - патрон з силікагелем; 9-12 - технологічний штуцер; 13,14 - опора

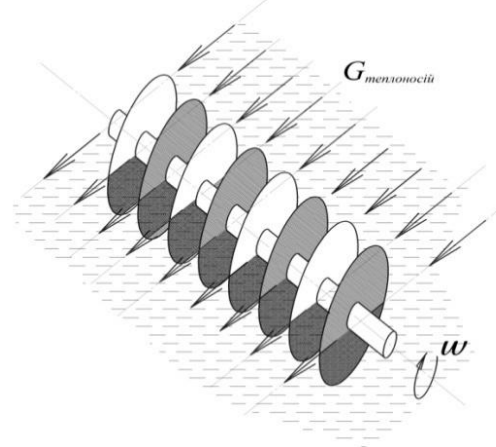

Рис. 2. Схем розміщення дисків в РПВА

Кількість тепла, яка необхідна для процесу концентрування (зневоднення) культурального розчину, визначалась [10], $\left(\frac{\text { кДж }}{\text { год }}\right)$ :

$$
\mathrm{Q}_{\text {вип.в. }}=\mathrm{G}_{\text {вип.в. }} \cdot \mathrm{r}+\mathrm{G}_{\mathrm{p}} \cdot \mathrm{c} \cdot \Delta \mathrm{t},
$$

де $G_{\text {вип.в. }}$ - кількість випареної вологи в процесі концентрування, $\left(\frac{\kappa г}{\text { год }}\right)$;

$\mathrm{r}$ - теплота пароутворення при середній температурі, $\left(\frac{\text { кДж }}{\text { год }}\right)$;

$\mathrm{G}_{\mathrm{p}}$ - кількість розчину, яка передається на концентрування, $\left(\frac{\kappa г}{\text { год }}\right)$;

c - теплоємність розчину, що концентрується, $\left(\frac{\kappa Д ж ~}{\kappa г \cdot г р а д) ; ~}\right.$

$\Delta \mathrm{t}$ - різниця температур розчину, що концентрується.

Кількість теплоносія, щоб підвести тепло на концентрування, $\left(\frac{\kappa г}{\text { год }}\right)$ :

$$
\mathrm{G}_{\mathrm{m}}=\frac{\mathrm{Q}_{\text {вип.в. }}}{\mathrm{C}_{\mathrm{m}} \cdot \Delta \mathrm{t}_{\mathrm{n}}}
$$


де $\mathrm{C}_{\mathrm{m}}$ - теплоємність теплоносія при середній температурі, $\left(\frac{\text { кДж }}{\kappa г \cdot г р а д ~}\right)$;

$\Delta \mathrm{t}_{\mathrm{m}}$ - різниця температури теплоносія:

$$
\Delta \mathrm{t}_{\mathrm{m}}=\mathrm{t}_{\mathrm{m}}^{\prime}-\mathrm{t}_{\mathrm{m}}^{\prime \prime},\left({ }^{\circ} \mathrm{C}\right),
$$

де $\mathrm{t}_{\mathrm{m}}^{\prime}$ - температура теплоносія, на вході в РПВА;

$\mathrm{t}_{\mathrm{m}}^{\prime \prime}$ - температура теплоносія на виході з РПВА.

Тепломасообмінна поверхня РПВА, ${ }^{2}$ :

$$
\mathrm{f}=\left[2 \frac{\pi \cdot \mathrm{D}^{2}}{4}\right] \cdot \mathrm{n}
$$

де D - діаметр однієї дискової насадки, м;

n - число дискових насадок, шт;

\section{5. Результати досліджень по зневодненню розчинів} метаногенів в роторно-плівковому випарному апараті

На експериментальному стенді роторно-плівкового випарного апарата (РВПА) (рис. 1) були проведені дослідження по концентруванню (зневодненню) розчинів метаногенів вирощених на мелясій барді, в залежності від температури та швидкості теплоносія, ступеню концентрування та $\mathrm{pH}$ розчину, побудовані криві швидкості та інтенсивності зневоднення (рис. 3, 4).

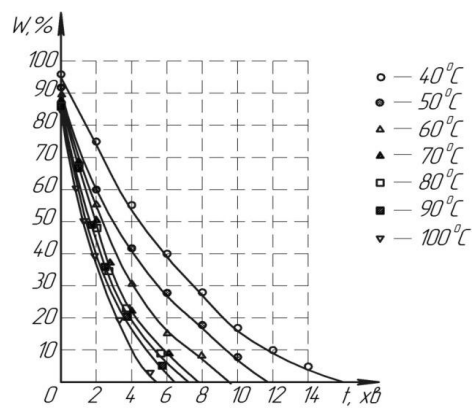

a

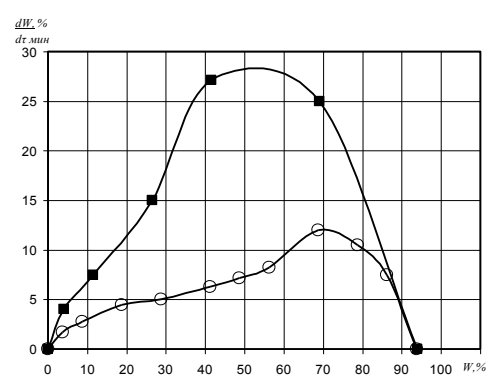

6

Рис. 3. Характеристика процесу зневоднення роторноплівкового випарного апарата: а - Криві швидкості зневоднення розчину метаногенів на мелясній барді, залежність кількості видаленої вологи W (\%) від часу $\tau$ (хв),

$б$ - Крива інтенсивності зневоднення розчину метаногенів на мелясній барді, залежність швидкості видалення вологи $\mathrm{dW} / \mathrm{d} \tau(\%)$ від кількості вологи W (\%). Швидкість теплоносія $\mathrm{v}=2,8 \mathrm{~m} /$ сек, Температура теплоносія $\mathrm{t}=40-100{ }^{\circ} \mathrm{C}$

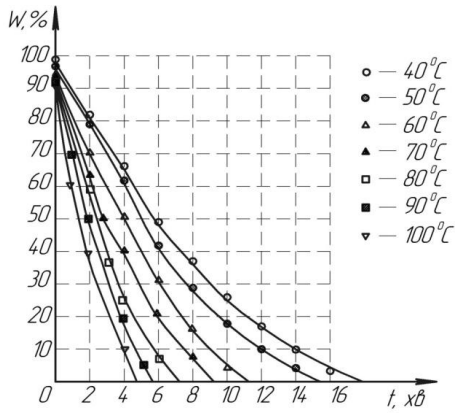

a

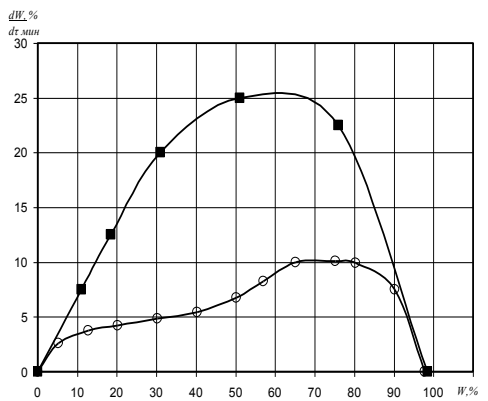

б

Рис. 4. Характеристика процесу зневоднення роторноплівкового випарного апарата: а - Криві швидкості зневоднення розчину метаногенів на спиртовій барді, залежність кількості видаленої вологи W (\%) від часу $\tau$ (хв.,), б - Крива інтенсивності зневоднення розчину метаногенів на спиртовій барді, залежність швидкості видалення вологи $\mathrm{dW} / \mathrm{d} \tau$ (\%) від кількості вологи W (\%). Швидкість теплоносія $\mathrm{v}=2,8$ м/сек, Температура теплоносія $\mathrm{t}=40-100^{\circ} \mathrm{C}$

Проведені експериментальні дослідження по зневодненню розчинів метаногенів вирощених на мелясній та спиртовій барді показали, що можливо приготувати композиційні розчини метаногенних бактерій, частково зневоднювати їх, виготовляти концентрати та застосовувати їх при запуску та збоях в роботі метантенків. Активність виготовлених метаноутворюючих концентратів була в межах $1-3 \times 10^{7}$ клітин/літр.

Необхідна кількість життєздатних клітин для інтенсифікації процесу метанового зброджування складає $10^{7-1} 0^{9}$ клітин/літр. Цей факт дає підстави вважати, що період протікання процесу прогнозовано зменшиться в 2 рази і складатиме орієнтовно 60 діб.

Аналіз досліджень показав (рис. 5), що швидкість теплоносія значного впливу на процес зневоднення та вихід життєздатних КУО не має, тому оптимальним параметром швидкості рекомендована $\mathrm{v}=2,8$ м/сек. Однак температура теплоносія мала визначальний характер на процес концентрування культуральної рідини і особливо на вихід життєздатних КУО. Було встановлено, що проведення процесу при температурі теплоносія від $40-60{ }^{\circ} \mathrm{C}$ давало змогу отримувати концентрат з високим вмістом життєздатних клітин (95-97 \%), але час концентрування був достатньо значним, що значно збільшувало енерговитрати. При температурі теплоносія від $90-100{ }^{\circ} \mathrm{C}$, процес зневоднення 
протікав достатньо швидко, але відзначався низький вихід живої культури до 30 \% у готовому концентраті.

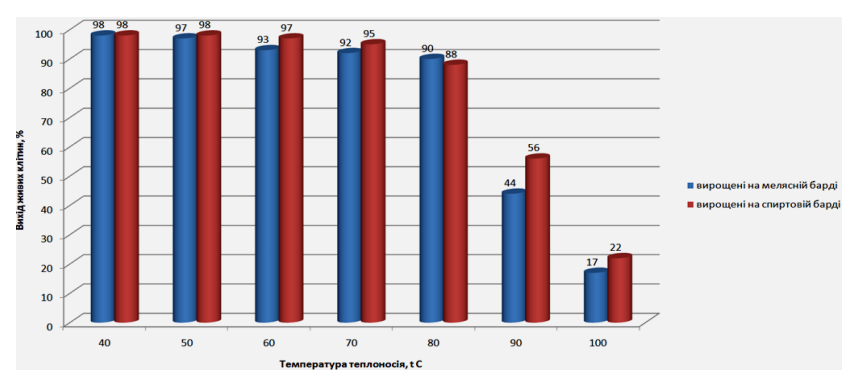

Рис. 5. Вихід живих клітин метаногенів (\%) в залежності від температури теплоносія $\left({ }^{\circ} \mathrm{C}\right)$

Це факт пояснюється тим, що всі досліди проводилися при однаковій швидкості обертання дискових насадок $\omega=60$ об/хв і при різних температурах теплоносія від 40-100 ${ }^{\circ} \mathrm{C}$. Тобто при більш високих температурах робочого теплоносія (більше $80{ }^{\circ} \mathrm{C}$ ) відбувається перегрів концентрату культуральної рідини, що без- посередньо впливає на вихід життєздатних клітин. Температура концентрату, не повинна перевищувати $40{ }^{\circ} \mathrm{C}$, при чому ступінь концентрування не повинен перевищувати 3.

Нами було встановлено, що оптимальною температурою теплоносія є інтервал від $60-80{ }^{\circ} \mathrm{C}$, оскільки процес концентрування відбувався відносно швидко, при незначних енерговитратах, а вихід життєздатних КУО був достатньо високим і складав (88-92 \%).

\section{6. Висновки}

- $\quad$ запропонована енергоефективна установка для концентрування термолабільних мікробіологічних матеріалів в анаеробних умовах;

- експериментально встановлені оптимальні режими концентрування: нейтральний $\mathrm{pH}=6-7$; швидкість теплоносія $\mathrm{v}=2,8 \mathrm{~m} / \mathrm{ce \kappa}$, температура теплоносія $60-80{ }^{\circ} \mathrm{C}$, температура концентрату $30-40{ }^{\circ} \mathrm{C}$, ступінь концентрування $-2,3$.

\section{Література}

1. Шидловський, А. К. Енергоефективність та відновлювані джерела енергії [Текст] / А. К. Шидловський // К.: Українські енциклопедичні знання - 2007. - 560 .

2. Бурга, Геммеке Биогаз на основе возобновляемого сырья. Сравнительный анализ шестидесяти одной установки по произе водству биогаза в Германии [Текст] / Геммеке Бурга, Ригер Криста, Вайланд Петер // Хофплатц.: Специальное агентство возобновляемых ресурсов (FNR) - 2010. - 115 .

3. Бекер, М. Е. Обезвоживание микробной биомассы [Текст] / М. Е. Бекер // Рига: Зинатне - 1967. - 361.

4. Бекер, М. Е. Биотехнология микробного синтеза [Текст] / М. Е. Бекер // Рига: Зинатне - 1980. - 350.

5. Новик, Г. И. Сохранение жизнеспособности и физиологических свойств бифидобактерий при криоконсервации и лиофилизации [Текст] / Г. И. Новик // Микробиология - 1998, т. 67, № 5. - с. 637 - 642.

6. Опарин, Ю. Т. Повреждение и защита биоматериалов при замораживании и лиофилизации [Текст] / Ю. Т. Опарин // Микробиология - 1996, № 7. - с. 3 - 13 .

7. Долинский, А. А. Кинетика и технология сушки распылением [Текст] / А. А. Долинский, К. Д. Малецкая, В. В. Шморгун // К.: Наук. Думка -1987. - 224.

8. Долинский, А. А. Технология и оборудование для сушки дрожжевых автолизатов [Текст] / А. А. Долинский, К. Д. Малецкая, А. Г. Заритовская // Промышленная теплотехника - 2003, т. 25. № 3. - с. 32 - 36.

9. Михалевич, В. В. Исследование процессов обезвоживания и гранулирования щелочной протеазы, щелочеустойчивой липазы [Текст] / В. В. Михалевич, Б. Н. Процишин // Пром. Теплотехника - 2000, т. 22. №5 - 6. - с. 54-58.

10. Куц, П. С. О некоторых закономерностях тепломассообмена при сушке бактериальных препаратов [Текст] / П. С.Куц, Э. Г. Тутова // Тепломассообмен - 1981. №7. - с. 418 - 425. 